\title{
Iodine I 124 Phospholipid Ether Analogue CLR1404
}

National Cancer Institute

\section{Source}

National Cancer Institute. Iodine I 124 Phospholipid Ether Analogue CLR1404. NCI

Thesaurus. Code C107500.

A small molecule radiopharmaceutical composed of the radioisotope iodine I 124 covalently attached to a proprietary alkylphospholipid ether (PLE) analogue, with potential imaging activity upon positron emission tomography (PET). Iodine I 124 phospholipid ether analogue CLR1404 is selectively taken up by tumor cells via membrane lipid rafts and accumulates in tumor cells. The accummulation of this agent is due to a decreased ability of tumor cells to metabolize PLEs because certain tumor cells have lower levels of the enzyme phospholipase- $D$, in comparison to normal cells. This facilitates imaging of cancer cells by PET. Lipid rafts, specialized microdomains of plasma membrane, are overexpressed in cancer cells compared to normal cells. In addition, the radioiodine moiety of this agent is resistant to de-iodination. 